\title{
PvuII Genetic Polymorphism of Low Density Lipoprotein Receptor in Human Immunodeficiency Virus Type 1-Infected Patients: Possible Association with Dyslipidemia
}

\section{Elaine Regina Delicato de Almeida ${ }^{1,2 *}$, Andréa Name Colado Simão ${ }^{1 *}$, Helena Kaminami Morimoto ${ }^{1,3^{*}}$, Ana Paula Kallaur ${ }^{3}$, Tamires Flauzino ${ }^{3}$, Daniela Frizon Alfieri ${ }^{3}$, Jair Aparecido de Oliveira' ${ }^{1}$, Luis Toshio Ueda ${ }^{4}$, Marcel Alysson Batisti Lozovoy', Isaias Dichi' ${ }^{5}$, Maria Angelica Ehara Watanabe ${ }^{6}$ and Edna Maria Vissoci Reiche ${ }^{1 \# \star}$}

${ }^{1}$ Department of Pathology, Clinical Analysis and Toxicology, Health Sciences Center, University of Londrina, Av. Robert Koch, 60, CEP 86.038-440, Londrina, Paraná, Brazil

${ }^{2}$ Pathological Sciences Postgraduate Program, Biological Sciences Center, University of Londrina, Av. Robert Koch, 60, CEP 86.038-440, Londrina, Paraná, Brazil ${ }^{3}$ Postgraduate Program of Health Sciences, Health Sciences Center, University of Londrina, Av. Robert Koch, 60, CEP 86.038-440, Londrina, Paraná, Brazil ${ }^{4}$ Integrated Center of Infectious Diseases of $17^{a}$ Secretariat of Health of Paraná, Londrina, Paraná State, Av. Manoel Ribas, 1, Londrina, Paraná, Brazil ${ }^{5}$ Department of Internal Medicine, Health Sciences Center, University of Londrina, Av. Robert Koch, 60, CEP 86.038-440, Londrina, Paraná, Brazil ${ }^{6}$ Laboratory of Study and Applications of DNA Polymorphisms, Department of Pathological Sciences, Biological Sciences Center, University of Londrina, Londrina; Campus university CEP 86051-990, Londrina, Paraná, Brazil

\#These authors contributed equally to this work

\begin{abstract}
Objective: The aim of this study was to evaluate the association between the Pvull polymorphism in the intron 15 of low-density lipoprotein receptor (LDLR) and dyslipidemia in human immunodeficiency type 1 (HIV-1)-infected individuals.

Methods: The study included 355 HIV-1-infected patients [100 antiretroviral-naïve and 255 on highly active antiretroviral therapy (HAART)]. The Pvull LDLR polymorphism was determined using PCR-RFLP methods and the lipid profile was evaluated by serum levels of total cholesterol (COL), triglycerides (TG), low-density lipoprotein cholesterol (LDL-C), and high-density lipoprotein cholesterol (HDL-C).

Results: Those patients on HAART showed higher COL, TG, and LDL-C levels than those HAART-naïve (207.0 vs. $175.0 \mathrm{mg} / \mathrm{dL}, p<0.0001 ; 167.0$ vs. $119.5 \mathrm{mg} / \mathrm{dL}, p<0.0001$, and 124.2 vs. $102.9 \mathrm{mg} / \mathrm{dL}, \mathrm{p}=0.0003$, respectively). The frequency of patients with increased levels of COL, TG, and LDL-C was higher among those on HAART than HAARTnaïve $(86.6 \%$ vs. $67.4 \%, p<0.0001 ; 80.9 \%$ vs. $69.7 \%, p=0.0380$, and $74.4 \%$ vs. $62.6 \%, p=0.0339$, respectively). The frequency of the Pvull LDLR genotypes did not differ among the patients according to COL, TG, and LDL-C levels $(p>0.05)$. However, the frequency of high HDL-C levels was higher among those patients carrying the P2P2 genotype $(11.8 \%$ vs. $5.6 \%, p=0.0398)$.

Conclusions: The results underscored that HAART are associated with dyslipidemia in some HIV-1-infected patients but not in all of them. Moreover, the results suggest that the P2P2 genotype of the Pvull LDLR polymorphism might be in part modulating the effect of HAART and HIV-1 infection in HDL-C levels and this genotype could be a beneficial genetic marker associated candidate with better lipid profile in these patients.
\end{abstract}

Keywords: Dyslipidemia; Low density lipoprotein receptor (LDLR); Genetic polymorphism; Human Immunodeficiency Virus (HIV); Highly Active Antiretroviral Therapy (HAART); High-density lipoprotein cholesterol (HDL-C); Hypercholesterolemia

\section{Introduction}

The introduction of the highly active antiretroviral therapy (HAART) in 1996 has dramatically reduced the mortality and morbidity of human immunodeficiency virus type 1 (HIV-1)-infected patients, leading to prolonged and improved quality of life, converting this infection into a chronic manageable disease [1].

It has become clear that HIV-1-infected patients have an increased risk of developing noninfectious consequences over time. Moreover, this longer life span has exposed these patients to the effects of aging, and other host and environmental factors known to increase the risk of obesity, diabetes, and cardiovascular disease (CVD) [2]. In the last few years, dyslipidemia, insulin resistance, central adiposity, oxidative stress, and lipodystrophy have been reported in several HIV-1-infected patients, and their relationship with HAART and HIV-1 infection per se have become a subject of debate and researches worldwide [3].

The pathogenesis of dyslipidemia in HIV-1 infection is complex and involves factors related to the host, virus, and antiretroviral therapy. This metabolic abnormality is frequently observed in HIV1 infected patients on HAART, demonstrated by increased levels of total cholesterol (COL), low density lipoprotein cholesterol (LDL-C), triglycerides (TG), and decreased high density lipoprotein cholesterol (HDL-C), constituting a highly atherogenic lipid profile [4-7].

To various degrees, multiple HIV-1 proteins and antiretroviral

*Corresponding author: Edna Maria Vissoci Reiche, Department of Pathology, Clinical Analysis and Toxicology, Health Sciences Center, University of Londrina, Av. Robert Koch, 60, CEP 86.038-440, Londrina, Paraná, Brazil, Tel: + 55-43-33712619; E-mail: reiche@sercomtel.com.br

Received July 30, 2014; Accepted October 10, 2014; Published October 12 2014

Citation: de Almeida ERD, Simão ANC, Morimoto HK, Kallaur AP, Flauzino T, et al. (2014) Pvull Genetic Polymorphism of Low Density Lipoprotein Receptor in Human Immunodeficiency Virus Type 1-Infected Patients: Possible Association with Dyslipidemia. J AIDS Clin Res 5: 362. doi:10.4172/2155-6113.1000362

Copyright: (C) 2014 de Almeida ERD, et al. This is an open-access article distributed under the terms of the Creative Commons Attribution License, which permits unrestricted use, distribution, and reproduction in any medium, provided the original author and source are credited. 
Citation: de Almeida ERD, Simão ANC, Morimoto HK, Kallaur AP, Flauzino T, et al. (2014) Pvull Genetic Polymorphism of Low Density Lipoprotein Receptor in Human Immunodeficiency Virus Type 1-Infected Patients: Possible Association with Dyslipidemia. J AIDS Clin Res 5: 362. doi:10.4172/2155-6113.1000362

drugs activate cell-signaling cascades, induce oxidative stress, disturb mitochondrial function, alter gene expression, and impair lipid metabolism. These changes occur in endothelial cells, vascular muscle cells, macrophages, adipocytes, and neuronal cells [8]. HIV-1 infection and HAART are also associated with accelerated atherosclerosis and an increased number of cases of myocardial infarction [9-10].

The type and severity of lipid abnormalities can vary according to the HAART regimen used. However, genetic factors may be involved with dyslipidemia, because not all patients exposed to same HAART regimen and comparable demographic, virological, and immunological characteristics, develop variations in the lipid profile $[11,12]$.

Hypercholesterolemia is the major risk factor for atherosclerosis and its premature cardiovascular complications. This dyslipidemic profile can be multifactorial or less frequently monogenic leading to autosomal dominant hypercholesterolemia (ADH) [13]. The first $\mathrm{ADH}$ causative gene identified was the low-density lipoprotein receptor(LDLR), located at chromosome 19p13.2, and encoding the LDL receptor (LDLR) [14]. Uptake of cholesterol is mediated by the LDLR and plays a crucial role in lipoprotein metabolism. The LDLR is responsible for the binding and subsequent cellular uptake of apolipoprotein-B and E-containing lipoproteins (apo B and apo E, respectively) [15].

To date, over 1200 mutations in $L D L R$ have been implicated in $\mathrm{ADH}$ [16]. Variations in $L D L R$ can interfere to a varying extent with all the different stages of the posttranslational processing, binding, uptake, and subsequent dissociation of the LDL-particle-LDLR complex [15]. Individuals who are carriers for such mutations exhibit two-fold increase or more in plasma COL levels and are at increased risk of developing atherosclerosis and coronary artery disease (CAD) [15]

The PvuII polymorphism, located at the intron 15 of the $L D L R$, has been considered a genetic marker linked to one of the variations in $L D L R$ expression that either structurally alters the receptor activity or alters its function in a regulatory manner [17]. This polymorphism has been associated with differences in LDL-C concentration in normo and hypercholesterolemic individuals from different countries [18].

Salazar et al. [19] carried out the first study with the PvuII $L D L R$ intron 15 polymorphismin a Brazilian population and described a strong association between the P1P1 genotype with high COL and LDL-C levels among the individuals with a lipid profile suggesting high risk for $\mathrm{CAD}$ and the normolipidemic individuals.

Taken into account that not all patients exposed to same HAART regime develop dyslipidemia, the aim of the present study was to evaluate the association between dyslipidemia and the PvuII LDLR polymorphism at the intron 15 in a cohort of HIV-1-infected patients in Southern Brazil that included both antiretroviral naïve and on HAART.

\section{Material and Methods}

\section{Study design}

The protocol of this cross-sectional study was approved by the Institutional Research Ethic Committee of the University of Londrina, Paraná State, Southern Brazil, and a written consent form was obtained from all of the individuals before the start of the study.

\section{Patients and control cohorts}

A total of 355 HIV-1-infected patients were consecutively recruited from Integrated Center of Infectious Diseases of $17^{a}$ Secretariat of Health of Paraná, Londrina, Paraná State, and from the Outpatient Clinical Hospital of University of Londrina, Paraná State. One hundred (28.2\%) were antiretroviral naïve and 255 (71.8\%) were on HAART including nucleoside reverse transcriptase inhibitors (NRTIs), nonnucleoside reverse transcriptase inhibitors (NNRTIs), and protease inhibitors (PIs). For all subjects included in the study, information on lifestyle factors and medical history were obtained at clinical evaluation. None of them was receiving a specific diet or reported habitual alcohol consumption. Body mass index (BMI) was calculated as weight $(\mathrm{kg})$ divided by height $(\mathrm{m})$ squared. Waist circumference was also measured and expressed as $\mathrm{cm}$.

\section{PvuII intron 15 polymorphism of the LDLR}

Peripheral blood cells were obtained with EDTA as anticoagulant; the samples were immediately centrifuged at 3,000 rpm for $15 \mathrm{~min}$, and the plasma and buffy coats were stored at freezer $-80^{\circ} \mathrm{C}$ until use. The samples were consecutively identified by number to guarantee confidentiality. The genomic DNA was extracted from buffy coat using DNA column purification reagent (Biopur, BiometrixDiagnóstica, Curitiba, Brazil) according to the manufacturer's instructions. The LDLR gene wasamp lified from 100-200 ng of genomic DNA using polymerase chain reaction (PCR) and the specific primers were determined according to previous reports $[17,19]$, as follow: Primer forward 5' -TCC CCT TCA AAA TGC CCT CTT-3'; Primer reverse 5'-AGC CAC CGA GCC CAG CCT AAG AA-3' (Invitrogen ${ }^{\mathrm{Tx}}$, Life Technologies, Carlsbad, CA, USA). PCR was performed with a final volume of $25 \mu \mathrm{L}$, with $2.5 \mathrm{mM}$ of each primer, $\mathrm{MgCl}_{2} 50 \mathrm{mM}$, dNTP $1.25 \mathrm{mM}$ (Invitrogen ${ }^{\mathrm{Tw}}$, Life Technologies, Carlsbad, CA, USA), Taq DNA polymerase $1.25 \mathrm{U}$ in the buffer provided (Invitrogen ${ }^{\mathrm{nx}}$, Life Technologies, Carlsbad, CA, USA), and $2 \mu \mathrm{L}$ of the DNA sample. PCR conditions were performed in a thermocycler (PCR Sprint-Thermo Hybaid $^{\mathrm{ix}}$, Biosystems, Barcelona, Spain) that comprised $5 \mathrm{~min}$ at $94^{\circ} \mathrm{C}$ for initial denaturation, 37 cycles of $45 \mathrm{sec}$ at $95^{\circ} \mathrm{C}$ for denaturation, 45 sec at $62^{\circ} \mathrm{C}$ for the anneling and $45 \mathrm{sec}$ at $72^{\circ} \mathrm{C}$ for the elongation, and $10 \mathrm{~min}$ at $72^{\circ} \mathrm{C}$ for final elongation. In all the PCR performed, negative control (without DNA sample) was included. The PCR products were evaluated using a $1.0 \%$ agarose gel electrophoresis and visualized by UV fluorescence after staining with ethidium bromide, as previously reported $[17,19]$.

Ten microliters of PCR products were completely digested with 0.3 $\mu \mathrm{L}$ of $P v u \mathrm{II} 10 \mathrm{U} / \mu \mathrm{L}$ enzyme (Invitrogen, Life Technologies, Carlsbad, CA, USA) for $4 \mathrm{~h}$ at $37^{\circ} \mathrm{C}$. The $P v u \mathrm{II} L D L R$ genotypes were identified by restriction fragment length polymorphism (RFLP) analysis in a $3 \%$ agarose gel electrophoresis $(70 \mathrm{~V}, 70 \mathrm{~min})$ and stained with ethidium bromide $[17,19]$. The $P v u \mathrm{II}$ cutting site (CAG $\downarrow$ CTG) is created by the substitution of a $\mathrm{C}$ to $\mathrm{T}$ within the sequence CAGCCG at a position about $900 \mathrm{bp}$ from the 3' end of exon 16. P2 variant allele includes a restriction site for $P v u \mathrm{II}$, which results in $200 \mathrm{bp}$ and $600 \mathrm{bp}$ fragments after digestion, the $\mathrm{P} 1$ allele is identified by one fragment of $800 \mathrm{bp}$, and the heterozygous genotype P1P2 is identified by three fragments $(800$ bp, $600 \mathrm{bp}$, and $200 \mathrm{bp}$ ). The PCR profiles were captured and recorded by photodocument system L-PIX-HE (LoccusBiotecnology, Cotia, Brazil).

\section{Lipid profile measurements}

Serum lipid levels were determined from blood samples obtained by venipuncture, without anticoagulant, following 10 to $12 \mathrm{~h}$ overnight fast. COL, TG, LDL-C, and HDL-C concentrations were measured by a biochemical analyzer Dimension Dade AR' (Dade Behring, Siemens Healthcare Diagnostics INC, Tarrytown, NY, United States). The results were expressed in $\mathrm{mg} / \mathrm{dL}$ and categorized according to the cut-off values used to define dyslipidemia according to the V Brazilian Guideline 
Citation: de Almeida ERD, Simão ANC, Morimoto HK, Kallaur AP, Flauzino T, et al. (2014) Pvull Genetic Polymorphism of Low Density Lipoprotein Receptor in Human Immunodeficiency Virus Type 1-Infected Patients: Possible Association with Dyslipidemia. J AIDS Clin Res 5: 362. doi:10.4172/2155-6113.1000362

Page 3 of 8

of Dyslipidemia and Prevention of Atherosclerosis, Department of Atherosclerosis of Brazilian Society of Cardiology [20].

\section{Statistical analysis}

The sample size was calculated with the Statcalc Program from Epi Info version $6.04 \mathrm{~d}$ and the data were evaluated using GraphPad Prism version 5.0 (GraphPad Software Inc., San Diego, CA). Categorical variables were analyzed using the Chi-square test, and expressed as the absolute (n) and relative (\%) numbers. Nonparametric continuous variables were analyzed using Mann-Whitney test and expressed as median and interquartile range (IQR) 25\%-75\%. To compare continuous variables from more than two groups, Kruskal-Wallis test was used, with Yates post-test. To evaluate the association between the genotypes and lipid profile of the HIV-1-infected patients, parameters such as age, gender, ethnicity, BMI, and waist circumference were controlled. The Hardy-Weinberg Equilibrium (HWE) was evaluated using the Chi-square test. The odds ratio (OR) and 95\% confidence interval $(95 \% \mathrm{CI})$ were also analyzed. All of the results were considered significant when $\mathrm{p}<0.05$.

\section{Results}

Demographic, anthropometric, and biochemical characteristics of HIV-1-infected patients enrolled in the study, according the use of HAARTornotare shown in Table 1. Caucasians and younger were more frequent among those HAART-naïve $(67.0 \% v s .55 .3 \%, \mathrm{p}=0.0440$; median $32.0 v s .42 .0$ years old, $\mathrm{p}<0.0001$ ), respectively. The patients on HAART showed higher TG (167.0 vs. $119.5 \mathrm{mg} / \mathrm{dL}, \mathrm{p}<0.0001)$, COL (207.0 vs. $175.0 \mathrm{mg} / \mathrm{dL}, \mathrm{p}<0.0001)$, and LDL-C (124.2 vs. $102.9 \mathrm{mg} / \mathrm{dL}$, $\mathrm{p}=0.0003)$ than those without HAART.

For univariate analysis, the lipid profile was categorized according to the dyslipidemia criteria for Brazilian population [20], and the patients were matched for gender, ethnicity, age, BMI, and waist circumference
(Table 2). The number of individuals with COL $\geq 200 \mathrm{mg} / \mathrm{dL}$ was higher among those on HAART $(86.6 \%$ vs. $67.4 \%$, OR=3.123, 95\% CI $=1.811$ $5.385, \mathrm{p}<0.0001)$ and on NRTIs regimen $(85.4 \%$ vs. $67.4 \%, \mathrm{OR}=2.823$, $95 \% \mathrm{CI}=1.659-4.803, \mathrm{p}<0.0002)$ than HAART-naïve. The number of patients with LDL-C levels $\geq 100 \mathrm{mg} / \mathrm{dL}$ was higher among those on HAART (74.4\% vs. $62.6 \%$, OR 1.739, 95\% CI $=1.070-2.825, \mathrm{p}=0.0248)$, on NRTIs ( $73.8 \%$ vs. $61.9 \%, \mathrm{OR}=1.739,95 \% \mathrm{CI}=1.073-2.818, \mathrm{p}=0.0239)$, and on NNRTIs $(31.4 \%$ vs. $19.4 \%, \mathrm{OR}=1.898,95 \% \mathrm{CI}=1.118-3.224$, $\mathrm{p}=0.0168)$ than HAART-naive. Moreover, the number of patients with TG $\geq 150 \mathrm{mg} / \mathrm{dL}$ was higher among those on HAART $(80.9 \%$ vs. 69.7\%, OR 1.841, 95\% CI=1.068-3.172, $\mathrm{p}=0.0380)$ and on PIs $(61.2 \%$ vs. $38.6 \%, \mathrm{OR}=2.500,95 \% \mathrm{CI}=1.554-4.020, \mathrm{p}=0.0002)$. Those patients on NRTIs displayed a trend towards higher frequency of TG $\geq 150 \mathrm{mg} /$ $\mathrm{dL}$ when compared to those without NRTIs; however, this difference did not reach statistical significance $(80.3 \%$ vs. $69.7 \%, \mathrm{OR}=1.767$, 95\% CI=1.029-3.025, $\mathrm{p}=0.0524)$. Regarding the $P v u \mathrm{II} L D L R$ intron 15 polymorphism, the frequencies of P1P1, P1P2, and P2P2 genotypes obtained among the HIV-1-infected patients were 52.4\%, 39.1\%, and $8.5 \%$, resulting an allelic frequency of 0.76 and 0.24 for P1 and P2 alleles, respectively. These frequencies were not significantly different from that predicted by the Hardy-Weinberg distribution ( $p>0.05$ ).

The frequency of the $P v u I I L L R$ genotypes did not differ according to serum COL, TG, and LDL-C levels in the HIV-1- infected patients $(\mathrm{p}=0.2682, \mathrm{p}=0.9590$, and $\mathrm{p}=0.5415$, respectively), as shown in Figure 1.

When HDL-C levels were categorized according to the gender of the HIV-1-infected patients and dyslipidemia criteria, the frequency of individuals with low HDL-C levels did not differ among those patients HAART-naive or on HAART ( $\mathrm{p}=0.8331)$. Moreover, the frequencies of low HDL-C did not differ according to the treatment with PIs, NRTIs, and NNRTIs ( $\mathrm{p}=0.2234, \mathrm{p}=0.8168$, and $\mathrm{p}=0.3890$, respectively) (Table 3). However, when the HDL-C values were evaluated according

\begin{tabular}{|c|c|c|c|}
\hline Characteristics & $\begin{array}{c}\text { Without HAART } \\
(n=100)\end{array}$ & $\begin{array}{l}\text { With HAART } \\
\quad(n=255)\end{array}$ & p value \\
\hline $\begin{array}{l}\text { Gender } \mathrm{n}(\%) \\
\text { Female } \\
\text { Male }\end{array}$ & $\begin{array}{l}52(52.0 \%) \\
48(48.0 \%)\end{array}$ & $\begin{array}{l}122(47.8 \%) \\
133(52.2 \%)\end{array}$ & 0.4810 \\
\hline $\begin{array}{l}\text { Ethnicity n (\%) } \\
\text { Caucasian } \\
\text { No Caucasian }\end{array}$ & $\begin{array}{l}67(67.0 \%) \\
33(33.0 \%)\end{array}$ & $\begin{array}{l}141(55.3 \%) \\
114(44.7 \%)\end{array}$ & 0.0440 \\
\hline Age (years) & $32.0(26.0-42.0)$ & $42.0(36.0-48.0)$ & $<0.0001$ \\
\hline Body mass index $\left(\mathrm{Kg} / \mathrm{cm}^{2}\right)$ & $24.4(21.3-26.9)$ & $24.2(21.5-27.2)$ & 0.9872 \\
\hline Waist circumference $(\mathrm{cm})$ & $89.0(80.3-96.0)$ & $90.0(84.0-98.0)$ & 0.1714 \\
\hline Triglycerides (mg/dL) & $119.5(78.8-160.8)$ & $167.0(105.0-229.0)$ & $<0.0001$ \\
\hline Total cholesterol (mg/dL) & $175.0(152.3-193.5)$ & $207.0(168.0-246.0)$ & $<0.0001$ \\
\hline LDL- cholesterol (mg/dL) & $102.9(86.3-127.5)$ & $124.2(93.0-152.0)$ & 0.0003 \\
\hline HDL- cholesterol (mg/dL) & $42.5(35.0-49.8)$ & $43.0(38.0-52.0)$ & 0.2042 \\
\hline CD3+T lymphocyte (cells/ $/ \mathrm{L}$ ) & $1466(939-2014)$ & $1627(1222-2036)$ & 0.3673 \\
\hline CD4+T lymphocyte (cells/ $\mu \mathrm{L}$ ) & $407(195-667)$ & $482(300-669)$ & 0.2849 \\
\hline CD8 ${ }^{+}$T lymphocyte (cells/ $\mu \mathrm{L}$ ) & $936(586-1239)$ & $1027(748-1331)$ & 0.2238 \\
\hline $\mathrm{TCD}^{+} / \mathrm{TCD} 8^{+}$ratio & $0.36(0.21-0.74)$ & $0.49(0.29-0.68)$ & 0.2689 \\
\hline HIV-1 Viral load (copies/mL) & 24990 (3377-94890) & $<50$ & $<0.0001$ \\
\hline HIV-1 Viral load $\left(\log _{10} / \mathrm{mL}\right)$ & $4.35(3.40-4.90)$ & $<1.70$ & $<0.0001$ \\
\hline
\end{tabular}

Chi-square test with Yates' correction. Mann-Whitney test. Data are expressed median (25\%-75\%). HAART: highly active antiretroviral therapy; LDL-C: low- density lipoprotein cholesterol; HDL-C: high-density lipoprotein cholesterol

Table 1: Demographic, anthropometric, and biochemical characteristics of human immunodeficiency type 1 (HIV-1)-infected patients from Southern Brazil, according to the therapy. 
Citation: de Almeida ERD, Simão ANC, Morimoto HK, Kallaur AP, Flauzino T, et al. (2014) Pvull Genetic Polymorphism of Low Density Lipoprotein Receptor in Human Immunodeficiency Virus Type 1-Infected Patients: Possible Association with Dyslipidemia. J AIDS Clin Res 5: 362. doi:10.4172/2155-6113.1000362

Page 4 of 8

\begin{tabular}{|c|c|c|c|c|c|c|}
\hline & $\begin{array}{c}C O L<200 \\
(n=184)\end{array}$ & $\begin{array}{c}\mathrm{COL} \geq 200 \\
(n=164)\end{array}$ & $\begin{array}{c}\text { LDL-C }<100 \\
(n=139)\end{array}$ & $\begin{array}{c}\text { LDL-C } \geq 100 \\
(n=172)\end{array}$ & $\begin{array}{l}\mathrm{TG}<150 \\
(n=132)\end{array}$ & $\begin{array}{c}T G \geq 150 \\
(n=157)\end{array}$ \\
\hline $\begin{array}{l}\text { Gender } \mathrm{n}(\%) \\
\text { Female } \\
\text { Male }\end{array}$ & $\begin{array}{c}77(41.8) \\
107(58.2)\end{array}$ & $\begin{array}{l}75(45.7) \\
89(54.3)\end{array}$ & $\begin{array}{l}49(35.2) \\
90(64.8)\end{array}$ & $\begin{array}{c}52(30.2) \\
120(69.8)\end{array}$ & $\begin{array}{l}54(40.9) \\
78(59.1)\end{array}$ & $\begin{array}{l}65(41.4) \\
92(58.6)\end{array}$ \\
\hline $\begin{array}{l}\text { Ethnicity n (\%) } \\
\text { Caucasian } \\
\text { No Caucasian }\end{array}$ & $\begin{array}{c}108(58.7) \\
76(41.3)\end{array}$ & $\begin{array}{c}100(61.0) \\
64(39.0)\end{array}$ & $\begin{array}{l}71(51.1) \\
68(48.9)\end{array}$ & $\begin{array}{l}88(51.2) \\
84(48.8)\end{array}$ & $\begin{array}{l}78(59.1) \\
54(40.9)\end{array}$ & $\begin{array}{l}97(61.8) \\
60(38.2)\end{array}$ \\
\hline Age (years) & $\begin{array}{c}40.0 \\
34.0-46.0\end{array}$ & $\begin{array}{c}42.0 \\
36.0-46.0\end{array}$ & $\begin{array}{c}38.0 \\
30.0-45.0\end{array}$ & $\begin{array}{c}40.0 \\
32.0-46.0\end{array}$ & $\begin{array}{c}40.5 \\
34.2-46.8\end{array}$ & $\begin{array}{c}41.0 \\
36.0-45.0\end{array}$ \\
\hline $\mathrm{BMI}\left(\mathrm{Kg} / \mathrm{cm}^{2}\right)$ & $\begin{array}{c}23.93 \\
20.96-26.79\end{array}$ & $\begin{array}{c}24.22 \\
21.68-27.29\end{array}$ & $\begin{array}{c}23.1 \\
20.7-26.0\end{array}$ & $\begin{array}{c}23.8 \\
21.5-26.4\end{array}$ & $\begin{array}{c}24.0 \\
21.7-26.9\end{array}$ & $\begin{array}{c}24.7 \\
22.4-27.1\end{array}$ \\
\hline WC (cm) & $\begin{array}{c}89.5 \\
82.5-94.8\end{array}$ & $\begin{array}{c}90.0 \\
86.0-98.0\end{array}$ & $\begin{array}{c}88.0 \\
81.0-97.0\end{array}$ & $\begin{array}{c}89.0 \\
84.0-95.0\end{array}$ & $\begin{array}{c}90.0 \\
84.0-97.0\end{array}$ & $\begin{array}{c}90.0 \\
87.0-98.0\end{array}$ \\
\hline $\begin{array}{l}\text { HAART n (\%) } \\
\text { Yes } \\
\text { No }\end{array}$ & $\begin{array}{c}124(67.4) \\
60(32.6)\end{array}$ & $\begin{array}{c}142(86.6)^{*} \\
22(13.4)\end{array}$ & $\begin{array}{l}87(62.6) \\
52(37.4)\end{array}$ & $\begin{array}{c}128(74.4)^{\ddagger} \\
44(25.6)\end{array}$ & $\begin{array}{l}92(69.7) \\
40(30.3)\end{array}$ & $\begin{array}{c}127(80.9)^{\prime \prime} \\
30(19.1)\end{array}$ \\
\hline $\begin{array}{l}\text { Pls n (\%) } \\
\text { Yes } \\
\text { No }\end{array}$ & $\begin{array}{l}85(46.2) \\
99(53.8)\end{array}$ & $\begin{array}{l}92(56.1) \\
72(43.9)\end{array}$ & $\begin{array}{l}59(42.4) \\
80(57.6)\end{array}$ & $\begin{array}{l}79(45.9) \\
93(54.1)\end{array}$ & $\begin{array}{l}51(38.6) \\
81(61.4)\end{array}$ & $\begin{array}{l}96(61.2)^{\pi} \\
61(38.8)\end{array}$ \\
\hline $\begin{array}{l}\text { NRTIs n (\%) } \\
\text { Yes } \\
\text { No }\end{array}$ & $\begin{array}{l}124(67.4) \\
60(32.6)\end{array}$ & $\begin{array}{c}140(85.4)^{\dagger} \\
24(14.6)\end{array}$ & $\begin{array}{l}86(61.9) \\
53(38.1)\end{array}$ & $\begin{array}{c}127(73.8)^{\S} \\
45(26.2)\end{array}$ & $\begin{array}{l}92(69.7) \\
40(30.3)\end{array}$ & $\begin{array}{c}126(80.3)^{* *} \\
31(19.7)\end{array}$ \\
\hline $\begin{array}{l}\text { NNRTIs n (\%) } \\
\text { Yes } \\
\text { No }\end{array}$ & $\begin{array}{c}42(22.8) \\
142(77.2)\end{array}$ & $\begin{array}{c}52(31.7) \\
112(68.3)\end{array}$ & $\begin{array}{l}27(19.4) \\
112(80.6)\end{array}$ & $\begin{array}{l}54(31.4)^{*, \pi} \\
118(68.6)\end{array}$ & $\begin{array}{l}41(31.1) \\
91(68.9)\end{array}$ & $\begin{array}{c}36(22.9) \\
121(77.1)\end{array}$ \\
\hline
\end{tabular}

Chi-square test with Yates' correction. Mann-Whitney test. Data are expressed median (25\%-75\%). COL: total cholesterol; LDL-C: low-density lipoprotein cholesterol; TG: triglyceride; BMI: body mass index; WC: waist circumference; IQR: interquartile range (25\%-75\%); HAART: highly active antiretroviral therapy; PIs: Protease inhibitors NRTIs: nucleoside reverse transcriptase inhibitors; NNRTIs: non-nucleoside reverse transcriptase inhibitors

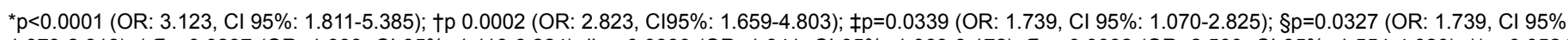

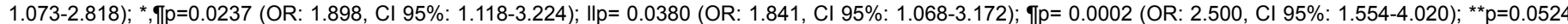
(OR: 1.767, Cl 95\%: 1.029-3.035)

Table 2: Demographic, anthropometric, and clinical characteristics of HIV-1-infected patients from Southern Brazil, according to the serum total cholesterol (TC), lowdensity lipoprotein cholesterol (LDL-C), and triglyceride (TG) levels.
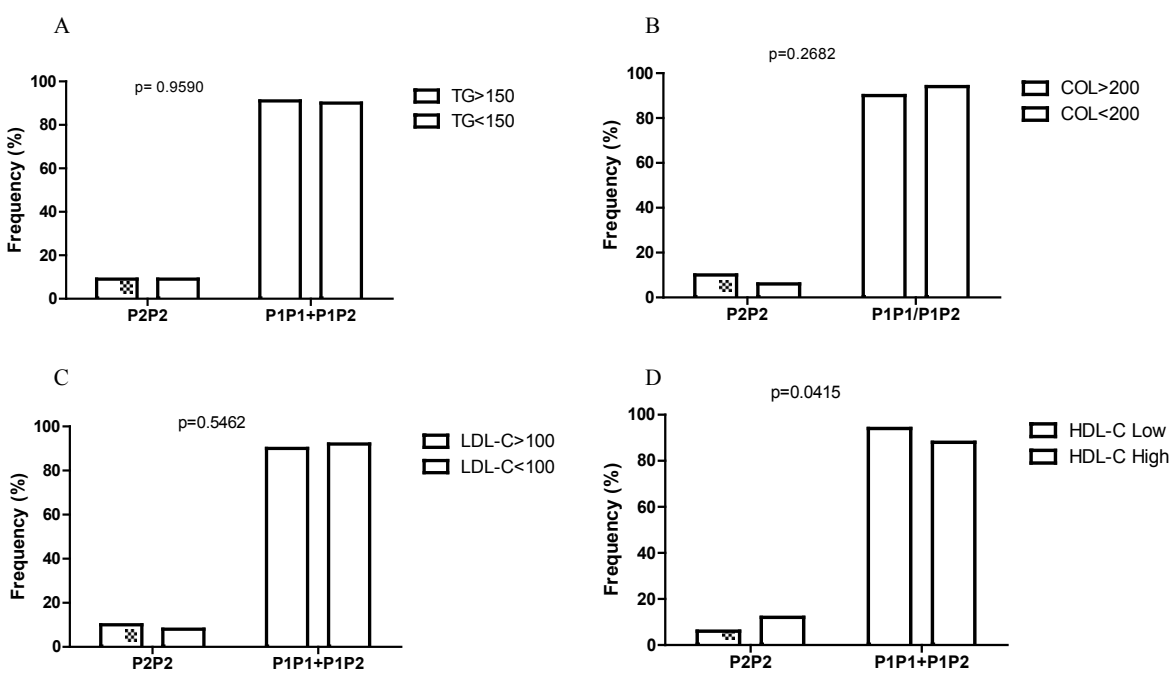

Figure 1: Frequency of the Pvull Low-Density Lipoprotein Receptor $(L D L R)$ genotypes according to the lipid serum levels of the human immunodeficiency virus type 1 (HIV-1)-infected patients.

Pvull LDLR polymorphism: P1/P1: homozygous genotype for the P1 allele; P1/P2: heterozygous genotype with the P1 and P2 alleles; P2/P2: homozygous genotype for the P2 allele.

to $P v u$ II $L D L R$ genotypes, the frequency of individuals with HDL-C $\geq 40 \mathrm{mg} / \mathrm{dL}$ for men and $\geq 50 \mathrm{mg} / \mathrm{dL}$ for women was higher among those carrying the $\mathrm{P} 2 \mathrm{P} 2$ genotype $(11.8 \%$ vs. $5.6 \%, \mathrm{OR}=0.4405,95 \%$ $\mathrm{CI}=0.1968-0.9860, \mathrm{p}=0.0415$ ) (Figure 1 and Table 3).

\section{Discussion}

This study reports, for the first time, the association between the lipid profile and the PvuII $L D L R$ intron 15 polymorphism among Brazilian HIV-1-infected patients HAART-naïve and on HAART. Despite 
Citation: de Almeida ERD, Simão ANC, Morimoto HK, Kallaur AP, Flauzino T, et al. (2014) Pvull Genetic Polymorphism of Low Density Lipoprotein Receptor in Human Immunodeficiency Virus Type 1-Infected Patients: Possible Association with Dyslipidemia. J AIDS Clin Res 5: 362. doi:10.4172/2155-6113.1000362

Page 5 of 8

\begin{tabular}{|c|c|c|c|}
\hline & $\begin{array}{l}\text { High HDL-C* } \\
\quad(n=152)\end{array}$ & $\begin{array}{l}\text { Low HDL-C† } \\
(n=179)\end{array}$ & $p$ value \\
\hline $\begin{array}{l}\text { Gender } n(\%) \\
\text { Female } \\
\text { Male }\end{array}$ & $\begin{array}{l}66(43.4) \\
86(56.6)\end{array}$ & $\begin{array}{l}83(46.4) \\
96(53.6)\end{array}$ & 0.5912 \\
\hline $\begin{array}{l}\text { Ethnicity } \mathrm{n}(\%) \\
\text { Caucasian } \\
\text { No Caucasian }\end{array}$ & $\begin{array}{c}102(67.1) \\
50(32.9)\end{array}$ & $\begin{array}{c}108(60.3) \\
71(39.7)\end{array}$ & 0.2025 \\
\hline Age (years) & $40.0(32.0-46.0)$ & $40.0(34.0-46.0)$ & 0.8785 \\
\hline Body mass index $\left(\mathrm{Kg} / \mathrm{cm}^{2}\right)$ & $23.6(21.2-26.3)$ & $24.4(21.7-27.0)$ & 0.2827 \\
\hline Waist circumference $(\mathrm{cm})$ & $90.0(84.2-98.0)$ & $90.0(84.0-96.0)$ & 0.3801 \\
\hline $\begin{array}{l}\text { HAART n (\%) } \\
\text { Yes } \\
\text { No }\end{array}$ & $\begin{array}{c}107(70.4) \\
45(29.6)\end{array}$ & $\begin{array}{c}129(72.1) \\
50(27.9)\end{array}$ & 0.8331 \\
\hline $\begin{array}{l}\text { Pls n (\%) } \\
\text { Yes } \\
\text { No }\end{array}$ & $\begin{array}{l}67(44.1) \\
85(55.9)\end{array}$ & $\begin{array}{l}92(51.4) \\
87(48.6)\end{array}$ & 0.2234 \\
\hline $\begin{array}{l}\text { NRTIs n (\%) } \\
\text { Yes } \\
\text { No }\end{array}$ & $\begin{array}{c}106(69.7) \\
46(30.3)\end{array}$ & $\begin{array}{c}128(71.5) \\
51(28.5)\end{array}$ & 0.8168 \\
\hline $\begin{array}{l}\text { NNRTIs n (\%) } \\
\text { Yes } \\
\text { No }\end{array}$ & $\begin{array}{c}42(27.6) \\
110(72.4)\end{array}$ & $\begin{array}{c}41(22.9) \\
138(77.1)\end{array}$ & 0.3890 \\
\hline $\begin{array}{l}\text { Genotypic analysis } \mathrm{n}(\%) \\
\text { P2P2 } \\
\text { P1P1+P1P2 }\end{array}$ & $\begin{array}{c}18(11.8) \\
134(88.2)\end{array}$ & $\begin{array}{c}10(5.6) \\
169(94.4)\end{array}$ & $0.0398^{* *}$ \\
\hline
\end{tabular}

Chi-square test with Yates' correction. Mann-Whitney test. Data are expressed median (25\%-75\%). *HDL-C: high-density lipoprotein cholesterol was considered HIGH: men $\geq 40 \mathrm{mg} / \mathrm{dL}$ and women $\geq 50 \mathrm{mg} / \mathrm{dL}$; †HDL-C: high-density lipoprotein cholesterol was considered LOW: $\mathrm{men}<40 \mathrm{mg} / \mathrm{dL}$ and women<50 mg/dL; $P$ vull $L D L R$ polymorphism: P1/P1: homozygous genotype for the P1 allele; P1/P2: heterozygous genotype with the P1 and P2 alleles; P2/P2: homozygous genotype for the P2 allele; HAART: highly active antiretroviral therapy; PIs: Protease inhibitors; NRTI: nucleoside reverse transcriptase inhibitors; NNRTIs: non-nucleoside reverse transcriptase inhibitors

${ }^{* *}$ OR: 0.3941 (Cl 95\%: 0.1715-0.9054)

Table 3: Demographic, genetic, clinical characteristics, and Pvull LDLR intron 15 polymorphism results of HIV-1-infected patients from Southern Brazil, according to the serum high-density lipoprotein cholesterol (HDL-C) levels.

Brazilian is one of the most genetically heterogeneous population worldwide, as the result of five centuries of interethnic crosses between peoples from three continents (Amerindians, Europeans and Africans) [21], the distribution pattern of the $P v u I I L D L R$ intron 15 genotypes obtained in the present cohort of HIV-1-infected patients seems to be similar to those observed in hypercholesterolemic patients from Israel, Italy, Spain, Netherlands and Denmark, London, North America, Switzerland, and Germany [18,22-24]. The frequency of the P1P1, P1P2 and $\mathrm{P} 2 \mathrm{P} 2$ genotypes obtained among the Italian population was $46.4 \%$, $43.2 \%$, and $10.4 \%$, respectively, and the P1 and P2 allelic frequency was 0.680 and 0.320 , respectively [25]. In our study, among the HIV1 -infected individuals from the Southern Brazilian population, the frequency of the P1P1, P1P2 and P2P2 genotypes was 52.4\%, 39.1\%, and $8.5 \%$, respectively, and the $\mathrm{P} 1$ and $\mathrm{P} 2$ allelic frequency was 0.76 and 0.24 , respectively. Moreover, it is comparable to a previous report among Brazilian individuals with a lipid profile suggesting high risk for CVD [19].

An association was demonstrated between COL levels and the $P v u I I$ LDLR genotypes in the Norwegian population [26], and in a sample of normolipidemic German population [27]. However, other study failed to demonstrate an increase in LDL-C levels [28]. These authors studied four different RFLPs for the LDLR gene, detected using the restriction enzymes StuI, $P v u \mathrm{II}, A p a \mathrm{LI}$, and NcoI, in normal subjects and in patients with familial hypercholesterolemia $(\mathrm{FH})$ from London and the results showed significant linkage disequilibrium between all four RFLPs and that people with different genotypes do not have significantly different levels of serum COL or LDL-C [28].

The present study failed to demonstrate the association between the $\mathrm{P} 2 \mathrm{P} 2$ genotype and low COL and LDL-C levels, as previously reported $[25,26,28]$. This result may be due to chance as well as to sample size, differences in genetic background or differences in the environmental factors that control sample variation. In general, plasma LDL-C levels are determined both by environmental factors, such as dietary fat intake, and genetic factors, and are the result of the balance between production and metabolism of apo B-containing lipoproteins from the liver and their rate of removal via receptor-independent and receptor-dependent pathways. Common variation in the $L D L R$ gene that affects either the affinity of the receptor for apo B in LDL or that affects expression of the gene and thus the number of receptors on the surface could contribute to inter-individual differences in plasma LDL-C levels. Moreover, considering the range in the reference values, sample size, and that the effect of the $P v u I I$ polymorphism is not strong in the LDL-C levels, difference in methods and commercial products that are used to determine serum lipid levels could be other factor to explain different results in lipid profile. As evaluated previously [25], the individuals with the genotype P1P2 or P2P2 exhibited mean LDL-C levels that were $11 \%$ and $20 \%$ lower, respectively, than those with the genotype P1P1. In addition, other variable sites of the $L D L R$ gene can be in strong linkage disequilibrium, and these different genetic variants could not act independently, raising the possibility that the effect on LDL-C associated with these variants may be explained by linkage disequilibrium with only a single functionally important sequence change at the LDLR locus [25].

The higher frequency of Caucasian and younger HIV-1-infected patients among those HAART-naive than those on HAART included in the present study is consistent with other report [29] and a possible 
Citation: de Almeida ERD, Simão ANC, Morimoto HK, Kallaur AP, Flauzino T, et al. (2014) Pvull Genetic Polymorphism of Low Density Lipoprotein Receptor in Human Immunodeficiency Virus Type 1-Infected Patients: Possible Association with Dyslipidemia. J AIDS Clin Res 5: 362. doi:10.4172/2155-6113.1000362

explanation could be the time of HIV-1 infection diagnosis. Probably, the Caucasians and younger had their HIV-1 infection more recently diagnosed or they were in an earlier phase of HIV-1 infection than nonCaucasians and older, when the HAART was not recommended at that time, according to the Brazilian government guidelines [30]. Despite high and increasing coverage with HAART, the HIV-1 infection represents a very clear example of the inequalities in access to health in the resource-limited countries, where, proportionally, more female are on antiretroviral treatment than men [31]. However, Brazil has a free and universal government program that guarantees access to HAART for all people living with HIV/AIDS who need this therapy and this may explain the similar gender distribution of patients on HAART observed in the present study.

HIV-1-associated dyslipidemia was recognized for years before the widespread use of PIs-based HAART and is characterized mainly by the decrease of COL, LDL-C, and HDL-C and, lately, elevated plasma TG [32-34]. The HIV-1 infection itself is the main responsible for low HDL-C levels, because several steps of HIV-1 replication critically depend on cholesterol $[35,36]$. In addition, over $60 \%$ of the patients that are on PIs develop metabolic changes, such as dyslipidemia with hypertriglyceridemia in the majority of cases, endothelial dysfunction, hyperglycemia, and central obesity [37,38]. The elevation of TG levels in patients who received PIs suggested that select PIs stimulate TG synthesis in hepatocytes [39]. PIs-associated dyslipidemia is a frequent class-related event and can limit their use especially in patients with preexisting increased cardiovascular risk. Different mechanisms are involved in the PIs-associated dyslipidemia, including the decreased expression of the $L D L R[25,37,40,41]$.

Mutations were detected in different domains of the LDLR [42] and have distinct impact on LDLR structure and function. The PvuII polymorphism is located in an intronic region of the $L D L R$ and may exert an indirect effect on cholesterol metabolism, probably by increasing the mRNA stability, activity, or increasing the number of LDLR on the cell surface. The intron $15 \mathrm{C} / \mathrm{T}$ change is unlikely to be an allelic marker for a functional sequence elsewhere at the gene locus [17]. This polymorphism has been associated with differences in LDL-C concentration in normo and hypercholesterolemic individuals from different countries. Individuals carrying the P2P2 genotype exhibited LDL-C levels $10-20 \%$ lower than those with other genotypes and an association between the $\mathrm{P} 2$ allele with lower levels of plasma lipids than the P1 allele was also reported [17,18,27]. Salazar et al. [19] described a strong association between the P1P1 genotype with higher COL and LDL-C levels among Brazilians with a lipid profile suggesting high risk for CAD and normolipidemic individuals.

An interesting result of the present study was that the frequency of low HDL-C levels observed among those patients on HAART did not differ according to the PIs, NRTIs, and NNRTIs regimens; however, when HDL-C values were evaluated according to $P v u I I L D L R$ intron 15 polymorphism, the number of individuals with HDL-C $\geq 40 \mathrm{mg} / \mathrm{dL}$ for men and $\geq 50 \mathrm{mg} / \mathrm{dL}$ for women was higher among those carrying the $\mathrm{P} 2 \mathrm{P} 2$ genotype, suggesting that the protective $\mathrm{P} 2 \mathrm{P} 2$ genotype could be modulating, in part, the effect of HIV-1 infection per se and of HAART in reducing HDL-C levels.

The mechanisms, by which the PvuII LDLR polymorphism may alter HDL-C levels, as observed in the present study, are unknown. The metabolism of HDL-C involves a complex interplay of factors regulating the synthesis, intravascular remodeling, and catabolism of HDL-C. Some hypotheses may explain the possible association between this polymorphism and the HDL-C levels, such as besides an increase in
LDL-C, a deficiency of the LDLR can modulate non-LDL lipoproteins in plasma as well, as recently reported [43].

Other hypothesis to explain why the mutation in the LDLR gene increased HDL-C levels could be supported, partly, by the function of the micro-RNAs (miRNAs). miRNAs have emerged as important regulators of lipoprotein metabolism. Over the past few years, it has demonstrated that miRNAs control the expression of most of the genes associated with HDL-C metabolism, including the ATP transporters, ABCA1 and ABCG1, and the scavenger receptor SRB1. These findings strongly suggest that miRNAs regulate HDL-C biogenesis, cellular cholesterol efflux, and HDL-C uptake in the liver, thereby controlling all of the steps of reverse cholesterol transport. Specifically, miR-33a/b and miR-122 have emerged as key regulators of genes involved in lipid metabolism, insulin signaling, and glucose homeostasis [44]. In this context, one of the hypotheses that could explain HDL-C increase in the presence of the $P v u I I L D R$ polymorphism is that this polymorphism in the intron 15 of the LDLR gene could generate or alter miRNAs that exert a role in lipid metabolism enhancing HDL-C synthesis. Thus, the study of the miRNAs associated with HDL-C metabolism may be other approach to evaluate the multifactorial etiology of dyslipidemia.

Some limitations of the study shoud be addressed. First, the individuals were age-sex-ethinicity and -BMI matched in the design proposed in order to control some important confounded variables that could interfere in the results, and this statistical approach reduced the number of individuals in some analysis; however, the statistical power of the study was maintained. Second, the study only evaluated one genetic variant associated with dyslipidemia. More than 400 genes are potential candidates to regulate lipid exchange and variations in a large number of genes involved in the synthesis of structural proteins and enzymes related with lipid metabolism. The main genes studied are those that encode proteins, receptors, and enzymes related to lipid metabolism and regulation. Polymorphisms in $L D L R$, apoE, apo $B$, apo A-I, apo C-III, apo A-V, PCSK9, CETP, and LP genes have been associated with changes in lipid profile [45]. Regarding the $L D L R$ gene, over 1,288 different variants have been implicated in the etiology of dslipidemia [46]. The evaluation of different genetic variants in the same cohort of individuals may identify a haplotype that could be a genetic marker of dyslipidemia for a specific population.

The complex polygenic trait of dyslipidemia among the HIV-1infected individuals has been demonstrated by a genome-wide study association (GWSA) that evaluated the contribution of 42 different SNPs and other variables, such as HAART, underlying conditions, sex, age, ethnicity, and HIV-1 disease parameters to dyslipidemia in 745 HIV-infected participants [47]. The results showed that the genetic background alone explained up to $7.6 \%$ of lipid variation in HIV-1infected patients (7.6\% non HDL-C, 6.2\% HDL-C, and 6.8\% TG), and HAART alone explained up to $6.2 \%$ of lipid variation $(3.9 \%$ non HDL-C, $1.5 \%$ HDL-C, and 6.2\% TG). The authors concluded that an individual with the most dyslipidemic antiretroviral and genetic background exhibited three to five-fold increased risk of sustained dyslipidemia compared with an individual with the least dyslipidemic therapy and genetic background.

Clinicians should consider the host genetic factors and the effects of HAART when selecting an antiretroviral regimen for HIV-1-infected patients. Because gene polymorphisms cause dyslipidemia, they should be investigated in these patients to identify individuals with an increased risk of developing dyslipidemia when on HAART, especially those containing PIs. This knowledge could guide individualized treatment decisions and lead to new therapeutic targets for the treatment of dyslipidemia [45]. 
Citation: de Almeida ERD, Simão ANC, Morimoto HK, Kallaur AP, Flauzino T, et al. (2014) Pvull Genetic Polymorphism of Low Density Lipoprotein Receptor in Human Immunodeficiency Virus Type 1-Infected Patients: Possible Association with Dyslipidemia. J AIDS Clin Res 5: 362. doi:10.4172/2155-6113.1000362

\section{Conclusions}

This study represents one of the first attempts at integrating the $P v u I I L D L R$ genetic variant with lipid profile in individuals who are living with HIV/AIDS among the Southern Brazilian population. Probably, the protector effect for dyslipidemia previously attributed to the $\mathrm{P} 2 \mathrm{P} 2$ genotype might be, partly, mitigating the deleterious effect of the HIV-1 infection and the HAART among the carriers of this genotype. Other known and novel genetic factors associated with lipid metabolism pathways should be investigated in this cohort of HIV-1-infected individuals in an attempt to identify genetic markers as candidates associated with dyslipidemia among the Brazilians. Moreover, gene products and pathways may provide new targets for development of more effective clinical strategies for these individuals.

\section{Acknowledgments}

This work was supported by Fundação de Apoio à Pesquisa (FAEP), State University of Londrina. T Flauzino and DF Alfieri have a Scientific Initiation gran from National Counsel of Technological and Scientific Development (CNPq), Ministry of Science and Technology, Brazil.

\section{References}

\section{UNAIDS (2012) World AIDS Day Report 2012.}

2. Volberding PA, Deeks SG (2010) Antiretroviral therapy and management of HIV infection. Lancet 376: 49-62.

3. Sudano I, Spieker LE, Noll G, Corti R, Weber R, et al. (2006) Cardiovascular disease in HIV infection. Am Heart J 151: 1147-1155.

4. Dubé MP, Cadden JJ (2011) Lipid metabolism in treated HIV Infection. Best Pract Res Clin Endocrinol Metab 25: 429-442.

5. El-Sadr WM, Mullin CM, Carr A, Gibert C, Rappoport C, et al. (2005) Effects of HIV disease on lipid, glucose and insulin levels: results from a large antiretroviral-naive cohort. HIV Med 6: 114-121.

6. Grunfeld C (2010) Dyslipidemia and its Treatment in HIV Infection. Top HIV Med 18: 112-118.

7. Tadewos A, Addis Z, Ambachew H, Banerjee S (2012) Prevalence of dyslipidemia among HIV-infected patients using first-line highly active antiretroviral therapy in Southern Ethiopia: a cross-sectional comparative group study. AIDS Res Ther 9: 31

8. Reiche EM, Simão ANC (2011) The role of human immunodeficiency virus type 1 (HIV-1) proteins and antiretroviral drug therapy in HIV-1-induced oxidative stress. In: HIV and AIDS: Updates on Biology, Immunology, Epidemiology and Treatment Strategies. InTech Open Access Publisher, Rijeka, Croatia, pp.4168.

9. Estrada V, Portilla J (2011) Dyslipidemia related to antiretroviral therapy. AIDS Rev 13: 49-56

10. Friis-Møller N, Weber R, Reiss P, Thiébaut R, Kirk O, et al. (2003) Cardiovascular disease risk factors in HIV patients--association with antiretroviral therapy. Results from the DAD study. AIDS 17: 1179-1193.

11. Arnedo M, Taffé P, Sahli R, Furrer H, Hirschel B, et al. (2007) Contribution of 20 single nucleotide polymorphisms of 13 genes to dyslipidemia associated with antiretroviral therapy. Pharmacogenet Genomics 17: 755-764.

12. Egaña-Gorroño L, Martínez E, Cormand B, Escribà T, Gatell J, et al. (2013) Impact of genetic factors on dyslipidemia in HIV-infected patients starting antiretroviral therapy. AIDS 27: 529-538.

13. Humphries SE, Norbury G, Leigh S, Hadfield SG, Nair D (2008) What is the clinical utility of DNA testing in patients with familial hypercholesterolaemia? Curr Opin Lipidol 19: 362-368.

14. Goldstein JL, Schrott HG, Hazzard WR, Bierman EL, Motulsky AG (1973) Hyperlipidemia in coronary heart disease. II. Genetic analysis of lipid levels in 176 families and delineation of a new inherited disorder, combined hyperlipidemia. J Clin Invest 52: 1544-1568.

15. Brown MS, Goldstein JL (1986) A receptor-mediated pathway for cholesterol homeostasis. Science 232: 34-47.

16. Leigh SE, Foster AH, Whittall RA, Hubbart CS, Humphries SE (2008) Update and analysis of the University College London low-density lipoprotein receptor familial hypercholesterolemia database. Ann Hum Genet 72: 485-498.

17. Gudnason V, Zhou T, Thormar K, Baehring S, Cooper J, et al. (1998) Detection of the low-density lipoprotein receptor gene Pvu II intron 15 polymorphism using the polymerase chain reaction: association with plasma lipid traits in healthy men and women. Dis Markers 13: 209-220.

18. Leitersdorf E, Chakravarti A, Hobbs HH (1989) Polymorphic DNA haplotypes at the LDL receptor locus. Am J Hum Genet 44: 409-421.

19. Salazar LA, Hirata MH, Forti N, Diament J, Giannini SD, et al. (2000) Pvu II intron 15 polymorphism at the LDL receptor gene is associated with differences in serum lipid concentrations in subjects with low and high risk for coronary artery disease from Brazil. Clin Chim Acta 293: 75-88.

20. Xavier HT, Izar MC, Faria Neto JR, Assad MH, Rocha VZ, et al. (2013) Diretriz Brasileira de Dislipidemias e Prevenção da Aterosclerose. Arq Bras Cardiol 101: 1-22.

21. Suarez-Kurtz G, Pena SD, Struchiner CJ, Hutz MH (2012) Pharmacogenomic Diversity among Brazilians: Influence of Ancestry, Self-Reported Color, and Geographical Origin. Front Pharmacol 3: 191.

22. Berkman N, Weir BS, Pressman-Schwartz S, Reshef A, Leitersdorf E (1992) Haplotype analysis at the low density lipoprotein receptor locus: application to the study of familial hypercholesterolemia in Israel. Hum Genet 88: 405-410.

23. Bertolini S, Coviello DA, Masturzo P, Zucchetto E, Elicio N, et al. (1992) RFLPs of the LDL-receptor gene: their use in the diagnosis of $\mathrm{FH}$ and in evaluation of different levels of gene expression on normal subjects. Eur $\mathrm{J}$ Epidemiol 8 Suppl 1: 18-25.

24. Humphries SE, Kessling AM, Horsthemke B, Donald JA, Seed M, et al. (1985) A common DNA polymorphism of the low-density lipoprotein (LDL) receptor gene and its use in diagnosis. Lancet 1: 1003-1005

25. Humphries S, Coviello DA, Masturzo P, Balestreri R, Orecchini G, et al. (1991) Variation in the low density lipoprotein receptor gene is associated with differences in plasma low density lipoprotein cholesterol levels in young and old normal individuals from Italy. Arterioscler Thromb 11: 509-516.

26. Pedersen JC, Berg K (1988) Normal DNA polymorphism at the low density lipoprotein receptor (LDLR) locus associated with serum cholesterol level. Clin Genet 34: 306-312.

27. Schuster H, Humphries S, Rauh G, Held C, Keller C, et al. (1990) Association of DNA-haplotypes in the human LDL-receptor gene with normal serum cholesterol levels. Clin Genet 38: 401-409.

28. Taylor R, Jeenah M, Seed M, Humphries S (1988) Four DNA polymorphisms in the LDL receptor gene: their genetic relationship and use in the study of variation at the LDL receptor locus. J Med Genet 25: 653-659.

29. Feeney ER, McAuley N, O'Halloran JA, Rock C, Low J, et al. (2013) The expression of cholesterol metabolism genes in monocytes from HIV-infected subjects suggests intracellular cholesterol accumulation. J Infect Dis 207: 628637

30. Brazil. Ministry of Health (2008) National Health Surveillance Agency Board National Program of STD and Aids. Recommendations for antiretroviral therapy in adults infected with HIV. Ministry of Health, Brasília, Brazil.

31. Muula AS, Ngulube TJ, Siziya S, Makupe CM, Umar E, et al. (2007) Gender distribution of adult patients on highly active antiretroviral therapy (HAART) in Southern Africa: a systematic review. BMC Public Health 7: 63.

32. Grunfeld C, Kotler DP, Hamadeh R, Tierney A, Wang J, et al. (1989) Hypertriglyceridemia in the acquired immunodeficiency syndrome. Am J Med 86: 27-31.

33. Penzak SR, Chuck SK (2000) Hyperlipidemia associated with HIV protease inhibitor use: pathophysiology, prevalence, risk factors and treatment. Scand $\mathrm{J}$ Infect Dis 32: 111-123.

34. Rose H, Woolley I, Hoy J, Dart A, Bryant B, et al. (2006) HIV infection and high-density lipoprotein: the effect of the disease vs the effect of treatment. Metabolism 55: 90-95

35. Mujawar Z, Rose H, Morrow MP, Pushkarsky T, Dubrovsky L, et al. (2006) Human immunodeficiency virus impairs reverse cholesterol transport from macrophages. PLoS Biol 4: e365.

36. Rader DJ (2006) Molecular regulation of HDL metabolism and function: implications for novel therapies. J Clin Invest 116: 3090-3100. 
Citation: de Almeida ERD, Simão ANC, Morimoto HK, Kallaur AP, Flauzino T, et al. (2014) Pvull Genetic Polymorphism of Low Density Lipoprotein Receptor in Human Immunodeficiency Virus Type 1-Infected Patients: Possible Association with Dyslipidemia. J AIDS Clin Res 5: 362. doi:10.4172/2155-6113.1000362

37. Carr A, Samaras K, Burton S, Law M, Freund J, et al. (1998) A syndrome of peripheral lipodystrophy, hyperlipidaemia and insulin resistance in patients receiving HIV protease inhibitors. AIDS 12: F51-58.

38. Calza L, Manfredi R, Chiodo F (2004) Dyslipidaemia associated with antiretroviral therapy in HIV-infected patients. J Antimicrob Chemother 53: 1014.

39. Lenhard JM, Croom DK, Weiel JE, Winegar DA (2000) HIV protease inhibitors stimulate hepatic triglyceride synthesis. Arterioscler Thromb Vasc Biol 20: 2625-2629.

40. Wang X, Chai H, Yao Q, Chen $\mathrm{C}$ (2007) Molecular mechanisms of HIV protease inhibitor-induced endothelial dysfunction. J Acquir Immune Defic Syndr 44: 493-499.

41. Tran H, Robinson S, Mikhailenko I, Strickland DK (2003) Modulation of the LDL receptor and LRP levels by HIV protease inhibitors. J Lipid Res 44: 1859-1869.

42. De Castro-Orós I, Pampín S, Bolado-Carrancio A, De Cubas A, Palacios L, et al. (2011) Functional analysis of LDLR promoter and 5' UTR mutations in subjects with clinical diagnosis of familial hypercholesterolemia. Hum Mutat 32: 868-872.
43. Rinninger F, Heine M, Singaraja R, Hayden M, Brundert M, et al. (2014) High density lipoprotein metabolism in low density lipoprotein receptor-deficient mice. J Lipid Res 55: 1914-1924.

44. Fernández-Hernado C, Ramiréz CM, Goedeke L, Suárez Y (2013) ATVB in Focus: MicroRNAs: From Basic Mechanisms to Clinical Application in Cardiovascular Medicine. Micro RNAs in metabolic disease. Artheroscler Thromb Vasc Biol 33: 78-185.

45. de Almeida ER, Reiche EM, Kallaur AP, Flauzino T, Watanabe MA (2013) The roles of genetic polymorphisms and human immunodeficiency virus infection in lipid metabolism. Biomed Res Int 2013: 836790.

46. Usifo E, Leigh SE, Whittall RA, Lench N, Taylor A, et al. (2012) Low-density lipoprotein receptor gene familial hypercholesterolemia variant database: update and pathological assessment. Ann Hum Genet 76: 387-401.

47. Rotger M, Bayard C, Taffé P, Martinez R, Cavassini M, et al. (2009) Contribution of genome-wide significant single-nucleotide polymorphisms and antiretroviral therapy to dyslipidemia in HIV-infected individuals: a longitudinal study. Circ Cardiovasc Genet 2: 621-628. 